\title{
Shame Is Already a Revolution: The Politics of Affect in the Thought of Gilles Deleuze
}

\section{Aislinn O’Donnell Maynooth University}

\begin{abstract}
The concept of shame is important for Deleuze's ethics and politics. In this essay, shame is positioned within a nexus of concepts: the intolerable, seeing, resistance, powerlessness, and belief in this world. If one has fallen short, it is not because of who one is, how one is seen, or how one has been judged, but it is, in part, because of one's failure to see what is intolerable. In this respect, shame, in particular 'the shame of the world', has the potential to be a proto-political and proto-ethical affect because it suspends and precludes the ready invocation of clichés and explanations that buttress us against reality. This disruption in turn opens a space for creativity and resistance.
\end{abstract}

Keywords: shame, Gilles Deleuze, resistance, indifference, intolerable, Primo Levi

\section{Stories of Shame}

Shame is the affect that most reveals our orientation to and dependence on others. Its searing intensity can cause us to hang our head in a futile effort to make ourselves invisible. It exposes us. Some, like Silvan Tomkins (1995), wonder at the way in which the feeling of shame can be so intolerable that some even prefer death to it. He describes it as a sickness in the self, but also sees it as the primary affect of intersubjective life. Dominant motifs in discourses on shame include the failure or

Deleuze Studies 11.1 (2017): 1-24

DOI: $10.3366 /$ dls.2017.0249

(C) Edinburgh University Press www.euppublishing.com/dls 
inadequacy of self in acceding to an ideal or to a moral standard set by oneself or others, assaults on self-esteem, social exclusion, and a painful sense of being positioned as object, thing-like or invisible, but some experiences of shame can also invite an ethical orientation to the Other and an opening to a shared world. Shame is intimately connected with our relationships with others, not simply because we internalise norms, values or standards, or because we may feel judged by others for who we are, but because we can feel ashamed for what others, even those who are strangers, have done or failed to do. Shame is an ambivalent affect that is unreliable, contingent and contextual, and it can, of course, be pernicious and debilitating when we are shamed for who we are or others are ashamed of us. Yet, we can also feel ashamed before the Other rather than for him or her, and we can feel ashamed of the state of our world. It might seem then curious that a philosopher like Deleuze would feel so drawn to the figurations of shame he finds in the writings of Primo Levi, the shame of being human and the shame of the world, yet perhaps it is not so surprising. The shame that interests him is one uncoupled from personal judgement or shaming mechanisms. It inverts the horizons so that the mechanisms of power, privilege, complicity, banality and judgement are laid bare. Such 'pre-personal' shame offers a normative position that does not prescribe how things ought to be but only constitutes a refusal or negation of the intolerable nature of the present, whilst recognising how we are all tainted by what others have done or failed to do. This does not mean that we are all guilty. Through these moments of disruption and recognition, a space opens up, inviting, without guarantee of success, resistance and creativity.

In certain respects, the shame of being human resembles discourses on moral shame, elemental shame, and even what Karl Jaspers calls 'metaphysical guilt', but Deleuze inverts those discourses so that it is not just that I feel ashamed when the Other looks at me and appeals to me, but rather that I become ashamed at those rare moments when I become aware of my shamelessness, banality, insensibility and indifference to others and to the world, my complicity in suffering, or when I witness the brutality and pettiness of human existence. That is, I become ashamed when my gaze turns outward and I see how things are and what is happening, such that what was previously invisible is suddenly seen as intolerable. Unlike those forms of shame that involve group identification, this shame does not categorise and classify humans privileging those whose perspectives I value, but it has a more expansive reach. It involves a seeing that is admittedly unpredictable, contingent and individual and does not offer a ground on which one could reliably 
base a substantive ethics or a politics. Rather like those unforeseeable encounters in teaching when the world opens for a student or teacher, aesthetic moments, including the experience of becoming undone that is wrought by shame, that shift our sensibilities can interrupt the complacency of ordinary life opening a space for critique, for the creation of new forms of resistance and creativity, and for the genesis of new becomings. This way of understanding shame is drawn in part from Primo Levi, Henri Bergson and Michel Foucault, and whilst it has affinities with the phenomenological and ethical approaches to shame developed by Levinas and Sartre, specifically in relation to the encounter with the Other, it is different, in respect of the antagonism of Sartre's account and the way in which Levinas understands responsibility for the Other.

In Being and Nothingness (2003), Jean-Paul Sartre argues that shame reveals our shared world despite the sense of vulnerability and exposure that I undergo when the Other looks at me. His interest in shame stemmed from his attempt to respond to the philosophical problem of solipsism and the question of the existence of the Other: unable to prove the existence of other subjects by means of the intellect or reason-for all I know, those that I think of as human might be marionettes or Descartes' clockwork men-the experience of shame reveals the unavoidable ontological vocation of my being-for-others. When Sartre's protagonist is, or imagines being, caught spying into a keyhole, shame is overwhelming. When the Other looks at me, I am pinned to my being, such that I no longer experience myself as freedom, but simply as an object or being-in-itself fixed by the gaze of the Other, the Other who kills off all my possibilities through that look. 'I am ashamed of what I am' (Sartre 2003: 221) but I am only ever ashamed before another and as I appear to the Other. This reveals, for Sartre, the ambiguity of being both being-for-itself and being-in-itself. The distance and reflexive relation to the self precipitated by the gaze of the Other is at once necessary for the constitution of a world, a shared world, and is a possible world, that is, a perspective on the world that is not mine. This experience of disintegration when the world falls away from me as though sucked towards a drain hole involves an experience of the Other that is non-cognitive and pre-reflective, provoking a relation to self that is strange, non-domesticated and oddly depersonalised. Shame's tonality, for Sartre, begins with becoming thing-like, akin to any other object or being, before the Other.

Such an experience of shame also reveals the existence of other subjects in the world, subjects whose reality is experienced viscerally 
as the face reddens and the head stoops. Others are thus encountered and experienced rather than 'known', as they elude the appropriative gaze by returning it. The Other is thus lived as shame. 'I depend on the other in my being. The other penetrates me to the heart' (Sartre 2003: 237). The turn from bare exposure to the conflictual exchange of the look begins once freedom is reasserted, as, sensing its vulnerability, the ego reacts defensively gathering the armoury of the free subject. Those short paragraphs that begin with the famous scene of the voyeur trace a movement from self-satisfaction or egoism to acute vulnerability and forced reorientation of the world, and finally back to a militant aggressive egoism. Whilst Sartre is right to underline that a reaction to shame can be expressed through anger, violence, conflict, resentment or aggression, other responses are possible. In her book, Artificial Hells, in a section called 'Artist as Torturer', Claire Bishop describes The Working Family by artist Oscar Bony. Bony placed an ordinary workingclass Argentinian family on a plinth, and paid the head of the family double his normal wages. She quotes Bony who said, 'I find it extremely important that there is a certain feeling of being at the limit', and another reviewer who wrote of the 'shared humiliation of looking at these people who have been paid in order to let themselves be seen' (quoted in Bishop 2012: 117). Bony himself said 'that the work was based on ethics, for exposing them to ridicule made me feel uncomfortable' (quoted in Bishop 2012: 117), which is why he referred to himself as the torturer.

Like Sartre, Levinas argued in his early 1935 essay 'On Escape' that in shame we feel ourselves naked, pinned down unable to hide from ourselves, unable to escape (Levinas 2002). The more we try, the more the body reddens and betrays. What shame reveals here, he says, is being's self-revelation, but this opaque, alien and impersonal self is unrecognisable: it is ex-timate. John Llewelyn writing of Levinas suggests that 'Shame is founded upon the solidarity of our being, which obliges us to claim responsibility for ourselves' (Llewelyn 1995: 63, quoting Levinas 2003: 63). In Levinas's later writings, shame opens us to the Other who concerns me. Rudi Visker writes:

The Other does not simply look at me. Its look concerns me. S/he is foisted upon me. This face cannot leave me indifferent, and the shame that overcomes me in the gaze of this appeal, even if I try to suppress it, reveals that I am more than libertas indifferentiae. (Visker 2004: 151)

Levinas's ideas shifted from 'On Escape', which he later disowned, but the question of shame continued to concern him as the shadow of genocide haunted his writing. Primo Levi asked in his chapter 'Shame' 
in The Drowned and the Saved, 'Are you ashamed because you are alive in place of another? And in particular, of a man more generous, more sensitive, more useful, wiser, worthier of living than you? You cannot block out such feelings [...].' (Levi 1988: 63). Levinas, responding to the same horror, writes:

My being-in-the-world or my 'place in the sun', my being at home, have these not also been the usurpation of spaces belonging to the other man whom I have already oppressed or starved, or driven out into a third world; are they not acts of repulsing, excluding, exiling, stripping, killing? Pascal's 'my place in the sun' marks the beginning of the image of the usurpation of the whole earth. (Levinas 1989: 82)

This radicalisation of the experience of shame highlights two of Levinas's supererogatory ethical commands: (1) substitution, as described by Levinas above, and (2) the singular injunction to respond before the face of the suffering other.

Such imagery of obedience and conversion conveys the involuntary nature of shame. Without deciding, without reflecting, without an interval, I am overwhelmed by the Other, fragile, exposed, singled out by the face of the Other who stretches out an empty hand. I must tear the food from my mouth. The significance of Levinas's innovation here cannot be understated. That which was a void for me, invisible, as I was consumed by myself, intent on appropriating and on preserving my own existence, suddenly makes its presence felt. Just like shame, this moment of conversion has no logical precursor. The responsibility for and before the Other is infinite and excessive. Shame itself is responsibility and one can never have done enough. Through shame, ethics arises. Through shame, one's egoism is undone.

\section{Invisibility, Indifference and Shamelessness}

The shame of not having understood, of not wanting to understand what has happened around you every day. [...]

For there is not a European who is not revolted, indignant, alarmed at everything, except at the fate to which the Arab is subjected.

Unperceived Arabs.

Ignored Arabs.

Arabs passed over in silence.

Arabs spirited away, dissimulated. [...]

And you mingling with those:

Who have never shaken hands with an Arab.

Never drunk coffee with an Arab. 
Never exchanged commonplaces about the weather with an Arab.

By your side the Arabs.

Pushed aside the Arabs.

Without effort rejected the Arabs.

Fanon 1964: 48

In 'Letter to a French Man', Franz Fanon levels a series of accusations at his correspondent and, by extension, at his reader. He describes as 'shame' the desire not to understand, a desire that sits comfortably with the propensity displayed by the coloniser to engage in empty moralising about Humanity whilst ignoring the brutal conditions of living human beings in their cities - the Arabs of Algeria. He writes knowing that most of those to and of whom he writes will remain untouched by shame. In The Wretched of the Earth he says, 'Leave this Europe where they are never done talking of Man, yet murder men everywhere they find them, at the corner of every one of their own streets, in all the corners of the globe' (Fanon 1963: 311). Words are hurled like weapons to try to make his reader see what is before him or her, yet this is often to no avail as such gestures are rejected when it is easier to obscure exploitation and marginalisation with ready-made explanations, rote responses and platitudes. This becomes even more likely when one is faced not only with the intolerable but also with one's complicity in its perpetuation.

Deleuze's interest in shame and shamelessness, the latter understood as indifference or insensibility, was developed through his exploration of the concepts and experiences of the intolerable, resistance, seeing and belief in the world. These are set against the backdrop of the horrors and disappointments of the twentieth century. Not responding is a form of shamelessness. Shamelessness, even if not referred to explicitly, is implicit in much of what Deleuze writes about the nature of experience in contemporary life, in particular when life seems less denied than anaesthetised or deadened. This is even the case when lived experience feels unliveable or lived at a distance from the body, perhaps distracted, anxious and over-stimulated so that little can hold interest for long. Such a tenor of existence is symptomatic of sad affects, the affects that cut us off from ourselves, from others and from experience. In Cinema 2, he describes this contemporary phenomenon vividly by saying:

The modern fact is that we no longer believe in this world. We do not even believe in the events which happen to us, love, death, as if they only half concerned us. It is not we who make cinema; it is the world which looks to us like a bad film. (Deleuze 1989: 171) 
If we are scarcely capable of experiencing life, let alone creating new possibilities of life, what could serve as a catalyst to shift our sensibilities?

Gilles Deleuze offers a reading of shame that, whilst resisting the ways in which life can become appropriative, egoistic, sedimented, habitual and unable to respond to the existence of others, is less focused on being seen or judged by the Other, than with one's indifference to the Other, and one's capacity to buffer oneself against what is intolerable in the world. He tries to find creative ways to de-personalise the self as a way to intensify life in order to sense more and perceive more. This singularisation of life opens one to the world. Like Levinas, he thinks that part of the problem is coming to see, feel and sense, but this is so that we can believe in the world or, as he says, the link between man and the world. If shame reveals our inability to be solitary, isolated, atomic or disconnected, it can help to counter the individualism of liberalism and capitalism without falling prey to the nihilism of fascism by operating at the level of desire and affect. It begins with the moment that one sees the intolerable. In this respect, the kind of shame that involves seeing rather than being seen does not involve feeling trapped, excluded or silenced, because it is not a personal affair. If one has fallen short, it is not because of who one is, but because of how one has been blind to others and to the possibilities of life. In this respect, shame has the potential to be a protopolitical and proto-ethical affect because it suspends and precludes the ready invocation of clichés and explanations. Shame reveals 'how it is', how this is impossible, but also how from such impossibility, something new may emerge to disrupt the dominant logic.

The sense of powerlessness precipitated by shame registers the diminishment of Life, human and non-human, organic and inorganic, but this need not lead to cynicism, nihilism or pessimism. The intensity of, and capacity for, seeing that can arise with the experience of shame and the perception of the intolerable in life invites the creation of a link between 'man and the world', a new kind of camaraderie and a confidence or belief in this world. This is consistent with the philosophies of joy that Deleuze is drawn to in Bergson, Spinoza and Nietzsche, and it provides him with a way of reworking the conundrum that people desire their own repression. The capacity to affect and to be affected is at the heart of Deleuze's philosophy of experience and of joy so it matters when we cease to be able to be affected. From Anti-Oedipus onward, Deleuze and Guattari argue that lifting the veils of false consciousness will not transform desire and will not enact revolutionary sentiments. Instead, a politics of desire requires disruption at the level of affective 
life in order to create a space for different ways of seeing, perceiving and thinking. Shame can be a precipitative force for both art and thought as it interrupts, however briefly, the stupidities, cruelties and clichés that foster insensibility and indifference to life, to possibility and to becoming.

What is required, Deleuze and Guattari argue, is a clinical and creative exercise of diagnosing 'becomings in every passing present' (Deleuze and Guattari 1994: 112). This concept of 'becoming' is a complex one. It describes at once the lived experience of duration, the zones of exchange and indetermination engendered through contiguity and proximity, and the line of flight that undoes fixity or stasis: 'and' is privileged over 'is', relations are privileged over essence or identity. Becoming-other requires encounters to bring us beyond ourselves, to move us, in order to help us to institute new forms of relationality. However, as Dominic Smith explains well in his analysis of shame in Deleuze and Levi, we have no guarantees: humans are capable of terrible things, of appalling stupidity and of dreadful banality (Smith 2007: 42). There are many ways in which life can be diminished and discarded, sensibility dulled, and experience thinned: Deleuze once said in a seminar, tell me what your affections are and I will tell you who you are. This is perhaps why the figure of the spiritual automaton, the Seer or visionary occupies such an important place in his later writings. Rather than reacting mechanically and habitually to stimuli and triggers, before even acting, one must first see the world with an overwhelming intensity that can open one once more to the possibility of creating a link with the world.

\section{Willed Ignorance}

But we had perceived without seeing.

Bergson 1965: 36

How and what we see makes a difference to how we understand ourselves, what we can sense, and how we move through the world. If, as Fanon and Primo Levi claim, we do not see, we desire to not understand, or we refuse to see, why is this the case? Bergson argues that it is in the nature of ordinary perception to see less rather than more: ordinary perception subtracts from things. Perception in everyday life is neither disinterested nor contemplative but operates as a function of utility, convenience and interest, enabling us to live in a very practical sense. However, the systematic elimination of what does 
not appear immediately useful or relevant can lead to the sensory-motor response that Deleuze calls 'cliché'. Clichés make it easier to ignore the 'mess', as Samuel Beckett says. Invoking platitudes is less discomfiting than facing the intolerable or abiding with a feeling of powerlessness when one knows neither how to respond nor what to do. Dullness of sensibility, narrowness of perception and stultification of thought further calcify through the repetition of ready-made reactions, leading to the alienation of humans from themselves, from one another and from the world. Clichés are imposed without sensitivity to context or matter, enabling us to tolerate almost anything. So a life lived through cliché encourages shamelessness, understood as indifference, insensibility or apatheia. However, when shame overcomes us, and shame is only ever involuntary, its intensity makes it impossible to remain indifferent. Deleuze writes:

We have schemata for turning away when it is too unpleasant, for prompting resignation when it is terrible, and for assimilating when it is too beautiful. It should be pointed out that even metaphors are sensory-motor evasions, and furnish us with something to say when we no longer know what to do. They are specific schemata of an affective nature. Now this is what a cliché is. A cliché is the sensory-motor image of the thing. Bergson says, we do not perceive the thing or the image in its entirety, we always perceive less of it, we only perceive what we are interested in perceiving, or rather what it is in our interest to perceive, by virtue of our economic interests, ideological beliefs and psychological demands. We therefore normally perceive only clichés. (Deleuze 1989: 20)

In The Drowned and the Saved, Levi calls 'willed ignorance', a deliberate refusal to see what is before one. He says, 'There are those who faced by the crime of others or their own, turn their backs so as not to feel touched by it [...]' (Levi 1988: 65). This is a vaster shame because those who might have done something chose to ignore what was happening, seeking to retrospectively justify themselves, or deciding not to ask too many questions. 'Not seeing was a way of not knowing and [...] not knowing relieved them of their share of complicity and connivance' (65). Shame was avoided through willed ignorance. However, avoiding shame was impossible for those exiled to the Lager, like Levi. He tells the Germans that they, the inhabitants of the camps, 'were not able not to see' as 'pain, past and present, surrounded us, and its level rose from year to year until it almost submerged us' (65).

No one in the camps either wanted to, or could, become an island but the factories of isolation, death, brutality and uniformity created a 
Hobbesian desert with rare moments of goodness. Levi then says with a terrible honesty:

The just among us, neither more nor less numerous than any other social group, felt remorse, shame and pain for the misdeeds that others and not they had committed, and in which they felt involved, because they sensed that what had happened around them, in their presence, and in them, was irrevocable. [...] It would prove that man, the human species-we, in short-were potentially able to construct an infinite enormity of pain; and that pain is the only force that is created from nothing, without cost and without effort. It is enough not to see, not to listen, not to act. (Levi 1988: 66)

Albert Camus (1961) meditates on what it means to be ashamed for someone else in 'Letters to a German Friend'. In the back of a truck, eleven Frenchmen are being transported to be shot. Five or six have done nothing to warrant this. 'The hour is harder for them because they are dying by mistake or as victims of a kind of indifference' (Camus 1961: 15). A sixteen-year-old boy sits there terrified. The chaplain seated amongst them tries to comfort him and encourage him to accept his imminent death. Later the boy spots a narrow space in the canvas and jumps from the truck. 'For a second the priest stares at those men looking at him in silence' (17) but then he alerts the drivers, 'Achtung!'. They give chase and the boy is recaptured. Camus writes of the shame one feels for and before the priest, at his hypocrisy, his betrayal, his complicity.

On a number of occasions Deleuze recalls how moved he was by Levi's short phrases 'the shame of being human' and 'shame of the world'. Shame does not here imply guilt, or even responsibility, and it cannot be readily transformed into courage as Len Lawlor and Janae Sholtz (2012) intimate. Shame tells us that we are all sullied and tainted by what we humans have done to one another, and by the state of our world - we are not islands. This is not to say we are guilty - to suggest so would be to diminish the acts and responsibility of the perpetrators. The feeling of shame can precipitate a sensory-motor break, its intensity forces us to see ourselves, whilst its solidary orientation (for good or ill) and the sociality required for its activation, undoes us, taking us beyond ourselves. Shame marks our interdependence - we are beings of relation, or, to use Deleuze's terminology, we are becomings-other. Although Deleuze acknowledges shame's composite nature, what is also of interest is the way in which shame is coupled with the resistance and the intolerable. This invites another way of understanding the relationship between shame, powerlessness, seeing and belief in the world - the motifs 
most commonly associated with the discussions of the intolerable in his work. One of his most important conceptual innovations in placing shame within this particular constellation of concepts was to uncouple it from judgement. Because shame invites consideration of the experience of the world and others, it serves as a reminder that that which is 'other' than us exists. In this respect, it is welcome because its disruptive quality helps to open us to becoming-other, to that which is not ourselves.

If the natural tendency of humans is to select or distort in order to ensure that perception is aligned with our interest, there is 'a constant effort of the mind to limit its horizon, to turn away from what it has a material interest in not seeing' (Bergson 1965: 13). This leads to the propensity to confuse the nature of things with what is simply useful. In Cinema 2, Deleuze argues that we live in a civilisation of clichés and that the task is to break through or get out of the cliché. Like Bergson, he believes that:

Everyday life can be nourished and illuminated by [bringing perception back to its origins]. For the world into which our senses and consciousness habitually introduce us is no more than the shadow of itself: and it is as cold as death. (Deleuze 1989: 128)

A dogmatic image of thought premised upon recognition and identity contributes to this deadening if it eliminates or incorporates what is new, unfamiliar, strange, different or intolerable, thus precluding contact with the real. In this respect, the importance of resisting clichés is not confined to critiques of mass culture, the cult of marketing or the cognitive or affective turns in contemporary capitalism. Rather, it evokes some of the central Bergsonian concepts that Deleuze examined throughout his life, including the complex relationship between epistemology, experience, ethico-political life and becoming. If Bergson teaches anything, it is that thinking, be it in the mode of ready-made ideas or intuition, is inseparable from pathos, perception, sensibility and affective life. If the problem is that we no longer believe in the world then the relational nature of shame may institute new forms of relationality. Concepts force us to see differently. But can an affect force us to see differently, and of all the affects, why is it shame that will help us come to face the intolerable, perhaps helping us believe in the world once more?

\section{Shame Is a Revolution}

Creating ways to resist capitalism and fascism is not straightforward. For Deleuze and Guattari, capitalism can always add another axiom in 
order to incorporate that which resists it, and fascism operates at the level of desire, which is why the masses desire their servitude more than their freedom. Explanations, reasoning or clarification therefore often change little in practice of living and the politics of everyday life. The transformation of modes of existence is not a simply cognitive matter of illuminating the minds of the people with the truth of 'how things are': revealing the fact of their repression will not work well as a strategy to dispel false consciousness. Radical change must first take place at the level of desire, affect and perception. This creates the potential for new kinds of assemblages and relations, and thus new modes of existence. The importance of shame for Deleuze's philosophy and politics derives from his attention to the importance of desire and affect in political life. Affect is often described as a passage or becoming that involves a lived transition from one affective state to another, in particular the elements relating to Nietzsche and Spinoza. However, certain affects, such as shame, involve vacillation or ambivalence that can be painful, paralysing and disquieting. In other experiences of affective life, there is a sense that power and the concomitant capacity to act has increased or decreased, with such variations indicating which relations or encounters agree with us, and which disagree. These variations are registered at the level of experience, felt as joy or sadness, and they condition the subsequent capacity to affect and be affected. In What is Philosophy?, the concept of affect takes on a different tenor as when Deleuze and Guattari say, 'The affect goes beyond affections no less than the percept goes beyond perceptions. The affect is not the passage from one lived state to another but man's nonhuman becoming' (Deleuze and Guattari 1994: 123). Although Spinoza viewed shame as a species of sadness, Deleuze understood it to be a potentially productive and critical affect.

This persistent invocation of a constellation of concepts-shame, the intolerable, seeing, powerlessness, resistance and belief-seems at odds with the overall orientation of Deleuze's philosophy of joy; however, once the broader context of his political and ethical concerns is underlined, it appears less so. In an interview with Antonio Negri, Deleuze says, 'Men's only hope lies in a revolutionary-becoming: the only way of casting off their shame or responding to what is intolerable' (Deleuze 1995: 171). The 'or' that separates 'shame' and the 'intolerable' here is best read as Spinoza's sive-casting off their shame, that is, responding to the intolerable. 'Revolutionary-becoming' is precipitated by an affect that is lived, undergone and impersonal, correlating with, or more precisely, registering the state of the world. Shame begins in and with an experience of impossibility and/or powerlessness. This is 
not the only way in which Deleuze will conceptualise shame, however, this reading is particularly interesting in that it refuses more familiar accounts of shame that rest upon the implicit or explicit judgement of (potential) others, without losing the intensity of what it means to undergo shame. His response to Negri also underlines his ambivalence in relation to shame - on the one hand it is to be cast off, but on the other hand resistance, or revolutionary-becoming, may emerge as a response to shame. Shame continues to remain here a strangely solidary rather than solitary affect, and the turbulent experience of shame may force one to 'see' the intolerable, an (impossible) experience that Deleuze will call visionary. Shame is, in this respect, a proto-political affect that Marx characterised well when he described shame as revolution. Resonant with this reading, John Marks writes:

'Shame' is a key theme in Deleuze's work, but a shame which is active and affirmative, rather than reactive and inward-looking. In simple terms, feeling shame at a personal level is of little interest to Deleuze, but there is an indefinite, impersonal form of shame. (Marks 2003: 115)

Whilst political philosophy must turn around the analysis of capitalism (Deleuze 1995: 171), philosophy itself is made political through shame. The shame of being human is 'one of the most powerful incentives towards philosophy' (Deleuze 1995: 172). Deleuze's positioning of shame in a revolutionary framework echoes Marx's very short reflections on shame and draws explicitly upon Primo Levi's 'shame of being a man' and 'shame of the world'. In his essay, 'In This Exile', Agamben comments that 'Marx still used to put some trust in shame' (Agamben 2000: 132). The short letter to which Agamben refers was written to Arnold Ruge 'on a barge to D. in 1843'. Marx claims that shame is an antidote to self-deception, saying, 'The glorious robes of liberalism have fallen away and the most repulsive despotism stands revealed for all the world to see' (Marx 1967: 204). Shame already is a revolution:

This, too, is a revelation, although a perverted one. It is a truth that at least teaches us to recognize the hollowness of our patriotism, the unnatural character of our government, and to turn our faces away in shame. Smiling, you look at me and ask, 'What is gained thereby? No revolution results from shame.' I answer, 'Shame already is a revolution.' Shame actually is the victory of the French Revolution over German patriotism by which the Revolution was conquered in 1813. Shame is a type of anger, introverted anger. And if a whole nation were to feel ashamed it would be like a lion recoiling in order to spring. (Marx 1967: 204) 
What does Marx mean when he says shame already is a revolution? He does not mean the debilitating experience of being shamed that may find expression and an outlet through anger or violence, or even the poetic rage of Pasolini's La Rabbia. This statement indicates, rather, a quality of affect that involves tension, incommensurability, disparateness, potential energy and perhaps ambivalence, experienced as intensified paralysis: action is delayed or suspended as one does not know what to do or how to respond, but respond one must. Sometimes there might be a sense of 'a complete margin where I already felt the pre-existence of objects yet to come, and of an entire field of virtualities and potentialities which I already knew were capable of being actualised' (Deleuze 1990: 305). However, writing of May 1968, Joan Copjec claims that Deleuze's account of affect becomes 'more murderous than murmuring' (Copjec 2006: 94), saying that affect 'is less a mantle surrounding perception than perception's inner division, its dislocation from itself' (2006: 94). Shame 'does not familiarize, domesticate or subjectivize - on the contrary, it estranges' (2006: 95). The estranging and paralysing experience that is shame performs an important role in the development of Deleuze's ethics and politics, and is related to his commitment to subvert the human tendency to assimilate that which is unfamiliar, strange and new. Becoming-other must be assembled at the level of desire, not at the level of the ideology or reason, and the disjunctive nature of the experience of shame helps to disrupt the smooth logic of capitalism. Capitalism, as Deleuze and Guattari emphasise throughout A Thousand Plateaus, can always add another axiom, appropriating and subsuming that which might serve as a challenge to its modus operandi.

Although shame can be used as a weapon of humiliation and a way of excluding those who do not fall within the parameters of the 'normal', this relates to a personal shame that is to do with who one is or how one feels one is seen. Deleuze is more interested in shame as a way of seeing. In order to think further about this, let us reflect upon a couple of examples from contemporary art practice. Santiago Sierra has developed works that precipitate complex experiences of shame in a way that resonates with the conceptualisation of shame developed by Deleuze. One of Sierra's works, a moving exhibition called the 'No, Global Tour', was a large half-ton sculpture on the back of a truck that simply stated, 'No'. His 'No' pieces have since been positioned in, or travelled through, different contexts constituting a form of refusal that itself refuses to engage in polemics or debate. Sierra's works are themselves often exploitative and through these 
(arguably) more minor forms of exploitation they lay bare a vaster exploitation that is intolerable. The works draw into relief the complicity of consumers with capitalist practices of expropriation and oppression, as well as the complicity of citizens with structured and systemic forms of abandonment, confinement and exclusion. In the artist's description of the action $160 \mathrm{~cm}$ Line Tattooed on 4 People (2000) Sierra says:

Four prostitutes addicted to heroin were hired for the price of a shot of heroin to give their consent to be tattooed. Normally they charge 2,000 or 3,000 pesetas, between 15 and 17 dollars, for fellatio, while the price of a shot of heroin is around 12,000 pesetas, about 67 dollars. ${ }^{1}$

If we, as many have done, respond to this provocation with outrage, why do we fail to respond with similar outrage to the everyday situation of these women? It may feel intolerable to witness such an action in situ or through its documentation, but the world in which these women live is intolerable and yet this is not remarked upon because such daily occurrences remain out of view, out of field and imperceptible, allowing us to deny or ignore our complicity in creating and sustaining intolerability in the lives of others.

Deleuze writes that 'There is no democratic state that's not compromised to the very core by its part in generating human misery' (Deleuze 1995: 173). Sierra's work makes us see the world that is before our eyes. Small acts of brutality lay bare the infinite and unapologetic cruelty of capitalism, leaving the viewer discomfited, without a way out, without escape, yet paradoxically without being riveted to one's being. Words like unease, ambivalence, hesitancy or even paralysis are often used to describe the experience of these pieces. We become ashamed because we are confronted with the ease with which we ordinarily tolerate that which is clearly intolerable and are unable to find a response that could smooth over our dilemma into a ready-made response or cliché. Shame in such instances can feel incomprehensible since we have done nothing. Such shame may appear irrational to others, in particular when the sense of shame was not catalysed by one's own action or inaction, or by a judgement on one's being, but simply by a shift in perception that changes our vision of what is before us. Phil Collins's film How to Make a Refugee (1999) participates in the unrelenting and exploitative lens and in situ editing of news crews who believe that the humanitarian mobilisation of shame will stop the violence of the perpetrators, yet it is Collins's ambivalence and complicity in the process that reveals the callous nature of the way in which images, like that of a young Kosovar refugee boy, are created 
for mass consumption. Shame marks and acknowledges complicity in oppression at an affective level, and this feels unbearable. Deleuze describes this as being responsible before rather than for-even though we are not all executioners, nonetheless we are tainted as humans by the actions of others.

\section{The Intolerable}

In Rossellini's Europa '51, the anti-heroine, Irene, tells her bourgeois friends and family what she has seen and learned in the tenement, the slum and the factory. 'I never knew,' she says. Her desire to give help to those in need is dictated by the situations that she encounters, appearing closer to logic than principle, but her steady refusal to return to her sheltered existence eventually leads to her institutionalisation. Beneath her window in the asylum her friends from the slums cry out that she is a saint, those in power, who will quickly agree to her indefinite internment, suspect that she may be one, while she says, 'I'd rather lose myself with others than save myself on my own.' Figures like Irene, Bartleby or Billy Budd populate Deleuze's texts. They are not political actors, nor are they creators of new possibilities of life, but they are important because they 'jam the machines' sufficiently to allow us to see, as Beckett will say, 'how it is'. A different example of this is found in the work of the artist Seamus Nolan, whose intervention, 'The 10th President of Ireland: William Delaney 1957-1970', involved asking the serving President of the Republic of Ireland, Michael D. Higgins, if he would hand over power to William Delaney for a nominal though symbolic period of time, be it a minute, an hour or a day. Willie Delaney is long dead, a child who died as a result of his internment in an institution through the head injuries that he suffered in Letterfrack Industrial School.

Francis McKee (2013) writes in the text accompanying the exhibition that:

[Nolan] understands the need to acknowledge the shame and the failed responsibility that accompanies the findings of the Ryan Report. For both the state and the citizen it is not enough in this situation to sentimentalise the victims and to evoke only sensations of pity and sadness. A fitting monument demands a dynamic moment acknowledging the disturbing truths of the situation, the anger and the pain, the abdication of responsibilities. (McKee 2013) 
Shame, rather than compassion or pity, accompanies the experience and recognition of the incommensurable and the intolerable. In his Proposal, Nolan writes:

this is a commemoration not just to the survivors of institutional abuse, but to those who did not survive, those who have been implicated by history in their silence and failure to intervene, and to those who are brave enough to acknowledge our collective failing and move forward in a process of healing. (McKee 2013)

In the Irish context, a long legacy of institutional abuse, and the complicity of Church, State, family and community in the practice of coerced institutionalisation makes it difficult for those who lived through the twentieth century to say, 'we never knew'. Even those who were children at that time, and those not yet born, can feel shame that this happened and can ask what the ether of the everyday and 'everyone knows' blinds us from seeing today, just as it did when the imprisonment of children and single mothers was 'normal'.

It is not assured that State and institutional responses to shame necessarily lead to more open and participatory institutions; they may lead to cover-ups and obfuscation through bureaucratic procedures or to more subtle and invisible methods of control. In Discipline and Punish, Michel Foucault describes the way in which the legal violence of the executioner became seen as shameful, leading to efforts by the system of justice to distance itself from the punishments it meted out. He writes that:

In modern justice and on the part of those who dispense it there is a shame in punishing, which does not always preclude zeal. This sense of shame is constantly growing: the psychologists and minor civil servants of moral orthopaedics proliferate on the wound that it leaves. (Foucault 1995: 10)

They encourage 'humane' punishment and rehabilitation: the technology of the soul. Yet even if responses to, for example, the shame of spectacular punishment bring with them their own shames and alternative shaming mechanisms, like the deficit views of the person in prison that underpin cognitive behavioural programmes or mandatory participation in life skills programmes, this does not mean that efforts to grasp and resist what is intolerable should abate. Teaching in a prison brought its own shames in my case, but the ethical imagination provoked by moving within those walls helped me to understand the lived implications of what Foucault calls the 'pseudo-sciences' and 
my complicity in legitimating the status quo by not contesting the authoritative claims made about human nature in those spaces.

Primo Levi outlines the complexity of this sense of complicity when he describes the strange phenomenon of the shame of those who did nothing to warrant such a feeling, exiled as they were to the Lager, just as he saw the shamelessness of those who were perpetrators of atrocity. He writes:

Another vaster shame, the shame of the world [when] those who faced by the crime of others or their own, turn their backs so as not to see and not feel touched by it: this is what the majority of Germans did during the twelve Hitlerian years, deluding themselves that not seeing was a way of not knowing, and that not knowing relieved them of their share of complicity of connivance. But we were denied the screen of willed ignorance. (Levi 1988: 65)

Deleuze and Guattari, following Levi, describe shame as a composite affect that is experienced not only before extreme situations, but also in trivial situations, 'in insignificant conditions, before the meanness and vulgarity of existence that haunts democracies, before the propagation of these modes of existence and of thought-for-the-market, and before the values, ideals and opinions of our time' (Deleuze and Guattari 1994: 107-8).

With little effort, one can find many examples of more 'minor' instances of shame. One summer, I stopped before two beluga whales in an aquarium in Valencia. Their sense of distress and depression was palpable as one persisted in hitting his blowhole up against the thick glass by the piping as though trying to breathe the world in, whilst the other swam frenetically up and down the narrow cage. It is hard not to feel shame at such moments. In the novel, Elizabeth Costello, the main protagonist, Elizabeth, describes the 'heavily affective sensation' of being a body, 'of being alive to the world' (Coetzee 2004: 78). She then remarks that:

fullness of being is a state hard to sustain in confinement. [...] To me it suggests that the freedom of the body to move in space is targeted as the point at which reason can most painfully and effectively harm the being of the other. (Coetzee 2004: 78)

She speaks of 'creatures least able to bear confinement' in laboratories or zoos and in institutions where the 'flow of joy that comes from [...] simply being an embodied being has no place' (Coetzee 2004: 78-9). Why is it so difficult to see this? 
One afternoon I walked with a young man, a prisoner, down the steel central stairs of the prison block in which I sometimes teach philosophy. We chatted as we walked and then the prison officer opened the gate. My instinct was to say, 'After you,' but I could not, and this small incivility, this inability to extend the tiniest of polite gestures, revealed that we lived in worlds apart-I walked out and he stayed behind. I felt ashamed that our difference was made so conspicuous through my failure of basic civility, even though it would have been an impossible act given the context to make this tiny gesture of politeness and decency, the kind of gesture that is the condition for any convivial existence. Having spent months trailing my fingers along the iron mesh and the bars, looking at the barbed wire against the sky, I understood all of a sudden: this is a prison, and what it does is intolerable, extending far beyond confinement, corroding the fabric of the last semblances of ordinary relationships. Coming to see what is intolerable sometimes only requires a tiny shift in perception like a gesture, a word, an omission or a story: 'It will be said that this enlarging is impossible. How can one ask the eyes of the body, or those of the mind, to see more than they can see?' (Bergson 1965: 35).

Deleuze turns to the example of Foucault's work on prisons and with prisoners when he describes Foucault as a kind of seer, saying, 'what he saw was actually intolerable' (Deleuze 2006: 274). He claims that for Foucault, thinking was a reaction to the intolerable, describing (1) thinking as experimentation, and (2) thinking as vision, 'as capturing the intolerable' (275). When asked whether this was a kind of ethics, he says the ethic was 'to see or grasp something as intolerable' (275). Yet, what made it intolerable was that no one saw it, 'it was imperceptible' (275) even though everyone 'saw' it, everyone knew. Foucault saw it. This involves seeing something imperceptible in the visible. 'It was two things: seeing something unseen and thinking something that was almost at a limit' (277). Deleuze moves between different positions in respect of the question of the intolerable. At times, it seems sufficient that we see and grasp the intolerable, yet at other moments, as in the interview with Negri, he states that we experience the intolerable and feel trapped:

For it is not in the name of a better or truer world that thought captures the intolerable in the world. On the contrary, it is because the world is intolerable that it can no longer think a world or think itself. The intolerable is no longer a serious injustice, but the permanent state of a daily banality. Man is not himself a world other than the one in which he experiences the intolerable and feels trapped. (Deleuze 1995: 169-70; original emphasis) 
Deleuze returns over and again to the question of the 'intolerable' in his later writings. Why is it that we cannot see what is before us? Why do we accept the intolerable? What makes the world intolerable? He writes:

In order for people to be able to bear themselves and the world, misery has to reach the inside of consciousness and the inside has to be like the outside. [...] People would not accept the intolerable if the same 'reasons' were not insinuating themselves in them in order to make them adhere from the inside. (Deleuze 1989: 209)

The question of the intolerable is undoubtedly complex and Deleuze mobilises the term in different ways depending on the context. In What is Philosophy?, and in his interviews, shame and the intolerable are invoked together. This is not the case in Cinema 2, but I want to argue, even if Deleuze does not do so explicitly, that coming to see can be part of the experience of shame precisely because shame forecloses a ready response by instituting a sensory-motor break that precludes automatic reaction (even if shame may quickly give rise to anger).

\section{Seeing and Belief in This World}

What counts is what amounted to a visionary phenomenon, as if a society suddenly saw what was intolerable and also saw the possibility for something else. It is a collective phenomenon in the form of: 'Give me the possible, or I will suffocate ...' The possible does not pre-exist, it is created by the event. It is a question of life. The event creates a new existence, it produces a new subjectivity (new relations with the body, with sexuality, the immediate surroundings, with culture, work ... ). (Deleuze 2006b: 234)

To see the intolerable is not enough; one must see the possibility for something else. The analysis of neo-realist cinema in Cinema 2 in which Deleuze describes the psychic situation of the seer is not just another contribution to studies on this particular era of film-making. It tells of the devastation of the post-war world in which denizens wander the earth, lost, unable to act, powerless, but capable of seeing the intolerable. Deleuze also finds these characters -Idiots, Seers - in other forms of the arts, like literature. They always fail to understand what everyone knows and they will not or cannot act as everyone commands. They do not appear to have the facility to react 'appropriately' to the situations in which they find themselves. They see rather than act. The Seer replaces the Agent-that intentional subject who examines the world, identifying his or her ends, and then deciding on the best means of action. Agency will not help to restore the world; what is 
needed is a character who 'sees better and further than he can react, that is, think' (Deleuze 1989: 169) because not power but powerlessness will help us to believe in life, and 'discover the identity of thought and life' (Deleuze 1989: 169). For Zourabichvili (2012), belief involves affirmation without knowledge, perception or thinking - we affirm what we cannot yet think. In what other ways might this strange formulation 'belief in the world' be understood? What can Deleuze mean when he says that 'The link between man and the world is broken' (Deleuze 1989: 171)? These statements return us to our initial reflections on clichés, on shame and the intolerable.

This aesthetic and political problem of the intolerable that is mapped in the delineation of the cinematic time-image in Cinema 2 is also a problem for life. When shame puts into crisis the complacency of everyday existence and common sense, drawing to visibility the impossibility of living under a given set of conditions, this marks a point of impasse and impotence. The experience also creates sensitivity to the richness of the present, to the forgotten histories, excluded others, silenced voices and unrealised worlds as well as to the real potentials of a concrete situation. Shame is excessive, rupturing the habits of the everyday, and drawing to light the limits of sensibility in a way that allows us to see. This disruptive force is the other face of becoming, the composition of relations and joyful affects that Nietzsche and Spinoza describe so well. (When I don't care, can't imagine, and can't begin to sense life from the standpoint of others, creating new becomings and forging links and connections is not only elusive, but I have no motivation to do so.) The project of restoring immanence is not another call to return to nature, but concerns rather an ethico-political proposition that wonders about the kinds of connections that a society might be capable of collectively creating.

Deleuze seldom used the word 'utopian and when he did, he did so with a good deal of reticence. A philosophy of immanence does not imagine and construct other worlds. John Llewelyn quotes a line of a poem attributed to Paul Éluard. It says, 'There is another world, but it's this one' (Llewelyn 2008: 307). This seems to capture something of Deleuze's exhortation 'to believe in the world'. Deleuze and Guattari say:

But, on the new plane, it is possible that the problem now concerns the one who believes in the world, and not even in the existence of the world but in its possibilities of movements and intensities, so as once again to give birth to new modes of existence, closer to animals and rocks. (Deleuze and Guattari 1994: 74) 
The originators of the Radical Enlightenment, Spinoza and Machiavelli, taught us that we must begin with how humans are, rather than how we would like them to be; since there is no other world, no heaven or hell, salvation must take place on this earth. Likewise, we must begin with the world and perceive the becomings of which it is capable. Becoming is not about transformation or change so much as about being open to instituting the communication of heterogeneous elements in unforeseeable ways. For one person, it might be Music for Eighteen Musicians by Steve Reich, for another the movement of a sparrow through the grass, for another being asked what they thought for the first time. We act as though the world does not exist or is apart from us so that we are not touched or moved by it. When we are overstimulated, as often we are in contemporary life, then 'boring holes', 'puncturing' and locating interstices, fissures and voids is one way of disrupting complacency, cynicism and clichés. I have suggested here that certain experiences of shame can be revolutionary in that they create, as Silvan Tomkins says, a silence in communication, allowing us to create something new. Deleuze and Guattari say, 'It is still necessary to discover, beneath the noise of actions, those internal creative sensations or those silent contemplations that bear witness to a brain' (Deleuze and Guattari 1994: 213). Shame invites such contemplation by precluding ready responses to stimuli and situations. It is a proto-political affect opening us to others and the world. However, shame will not make a revolution, even if it is itself already a revolution. Yet, perhaps the intensity of undergoing a shame that forces us both to see the world and to grasp our complicity in its impoverishment and misery may invite a different relation to the world. If we must come to believe in the world, which means believing in the link between man and the world, we have to see that the link has been broken. Deleuze writes:

The concept must be replaced with the 'percept', that is with a perception in becoming. It requires a new community whose members are capable of trust or 'confidence', that is, of a belief in themselves, in the world and in becoming.

(Deleuze 1998: 87-8)

A different perceptual politics, an involuntarist politics, forces us to see that which we do not wish to perceive.

\section{Note}

1. < http://www.tate.org.uk/art/artworks/sierra-160-cm-line-tattooed-on-4people-el-gallo-arte-contemporaneo-salamanca-spain-t11852/text-summary > (last accessed 10 October 2016). 


\section{References}

Agamben, Giorgio (2000) Means Without End: Notes on Politics, trans.Cesare Casarino and Vincenzo Binetti, Minneapolis: University of Minnesota Press

Bergson, Henri (1965) The Creative Mind, trans. Mabelle L. Andison, Totowa, NJ: Littlefield, Adams.

Bishop, Claire (2012) Artificial Hells, London: Verso.

Camus, Albert (1961) Resistance, Rebellion, and Death, trans.Justin O'Brien, New York: Alfred Knopf.

Coetzee, J. M. (2004) Elizabeth Costello, London: Vintage.

Copjec, Joan (2006) 'May ‘68, The Emotional Month', in Slavoj Žižek (ed.), Lacan: The Silent Partners, London: Verso, pp. 90-114.

Deleuze, Gilles (1989) Cinema 2: The Time-Image, trans. Hugh Tomlinson, Minneapolis: University of Minnesota Press.

Deleuze, Gilles (1990) The Logic of Sense, trans. Mark Lester with Charles Stivale, New York: Columbia University Press.

Deleuze, Gilles (1995) 'Control and Becoming', in Negotiations, trans. Martin Joughin, New York: Columbia University Press.

Deleuze, Gilles (1998) Essays Critical and Clinical, London: Verso.

Deleuze, Gilles (2006a) 'Foucault and Prison', in Two Regimes of Madness: Texts and Interviews 1975-1995, ed. David Lapoujade, trans. Ames Hodges and Mike Taormina, New York: Semiotext(e), pp. 272-81.

Deleuze, Gilles (2006b) 'May '68 Didn't Happen', in Two Regimes of Madness: Texts and Interviews 1975-1995, trans. Ames Hodges and Mike Taormina, New York: Semiotext(e), pp. 233-6.

Deleuze, Gilles and Félix Guattari (1994) What is Philosophy?, trans. Hugh Tomlinson, London: Verso.

Europa '51, directed by Roberto Rossellini. Italy: Ponti-De Laurentiis Cinematografica, 1952

Fanon, Franz (1963) The Wretched of the Earth, trans. Constance Farrington, New York: Grove Press.

Fanon, Franz (1964) Towards the African Revolution, trans. Haakon Chevalier, New York: Grove Press.

Foucault, Michel (1995) Discipline and Punish, trans. Alan Sheridan, London: Vintage.

How to Make a Refugee, video art. Phil Collins, 1999.

Lawlor Leonard and Janae Sholtz (2012) Presentation at Deleuze Conference, New Orleans, July.

Levi, Primo (1988) The Drowned and the Saved, trans. Raymond Rosenthal, London: Little, Brown.

Levinas, Emmanuel [1988] (2003) On Escape, Stanford: Stanford University Press.

Levinas, Emmanuel (1989) 'Ethics as First Philosophy', in Seán Hand (ed.), The Levinas Reader, Oxford: Blackwell.

Levinas, Emmanuel (2002) On Escape, trans. Bettina Bergo, Stanford: Stanford University Press.

Llewelyn, John (1995) Emmanuel Levinas: The Genealogy of Ethics, London: Routledge.

Llewelyn, John (2008) Margins of Philosophy: Between Kierkegaard and Derrida, Bloomington: Indiana University Press.

McKee, Francis (2013) 'The Visible Spectrum', in Seamus Nolan, Willie Delaney: 10th President of Ireland, catalogue, available at < http://www.10thpresident.org/ new-page/ > (last accessed 18 October 2016).

Marks, John (2003) 'Gilles Deleuze: Writing in Terror', Parallax, 9:1, pp. 114-24. 
Marx, Karl (1967) Writings of the Young Marx on Philosophy and Society, trans. Loyd D. Easton and Kurt H. Guddat, New York: Doubleday.

Sartre, Jean-Paul (2003) Being and Nothingness, trans. Hazel Barnes, London: Routledge.

Smith, Dominic (2007) 'Deleuze's Ethics of Reading: Deleuze, Badiou, and Primo Levi', Angelaki, 12:3, pp. 33-55.

Tomkins, Silvan (1995) Shame and Its Sisters, ed. Eve Kosofsky Sedgwick and Adam Frank, Durham, NC: Duke University Press.

Visker, Rudi (2004) The Inhuman Condition, Pittsburgh, PA: Duquesne University Press.

Zourabichvili, François (2012) Deleuze: A Philosophy of the Event: Together with The Vocabulary of Deleuze, ed. Gregg Lambert and Daniel W. Smith, trans. Kieran Aarons, Edinburgh: Edinburgh University Press. 